\title{
Neutrophil Elastase and Trastuzumab Responsiveness
}

\author{
Michiko Harao ${ }^{a}$ Takashi Sato ${ }^{b}$ Takashi Fukutomic Kyoko Yorozuya ${ }^{c}$ Miyuki Takasugi ${ }^{c}$ \\ Yukako Mohric Takao Mizumoto ${ }^{a}$ Satoshi Takahashid ${ }^{d}$ Jun-ichi Yamashita ${ }^{d}$ \\ a Department of Surgery, Kumamoto University Medical School, \\ ${ }^{b}$ Department of Otolaryngology, Aichi-Gakuin University, \\ ${ }^{\mathrm{c}}$ Department of Breast and Endocrine Surgery, Aichi Medical University, \\ ${ }^{d}$ Department of Breast Oncology, Okazaki City Medical Association Public Health Center, Japan
}

\section{Dear Editors,}

There are three well-characterized mammalian elastases. The best characterized is the porcine pancreatic elastase I, which is a serine protease secreted in a zymogen form by pancreatic acinar cells. The second class of mammalian elastases is neutrophil elastase (NE), the neutral protease found in granules of human neutrophils. A third mammalian elastase is a metalloprotease, secreted by inflammatory macrophages. Of these elastases, NE is the only neutral protease that is able to degrade insoluble elastin. NE can also hydrolyze other extramatrix proteins, including fibronectin, proteoglycans, and type IV collagen. Since the invaded tissues of tumor consist mainly of these components, we could guess that cancer cells might produce NE. In order to verify this hypothesis, an in vitro experiment has been conducted using breast cancer cell lines; we first demonstrated that immunoreactive NE was produced by breast cancer cells per se [1]. Furthermore, immunoreactive NE concentration in tumor extracts is an independent prognostic factor in patients with primary breast cancer [2], suggesting that tumor NE may play an active role in tumor progression that leads to metastasis in human breast cancer.

How does the increased NE in cancer cells make the cancer more malignant? Recently, some researchers have clarified the signaling structure of NE [3, 4]; NE can split cell surface epidermal growth factor (EGF) or transforming growth factor (TGF)-alpha from the cell membrane. Thus, it is conceivable that the splitting EGF or TGF-alpha from cancer cells may send signals to their own EGF receptors, making the cancer cells more malignant, because many cancer cells have EGF receptors in abundance, including breast cancer cells.

Trastuzumab is a recombinant humanized antihuman epidermal growth factor receptor 2 (HER2) monoclonal antibody engineered from a cloned human $\mathrm{IgG}$ framework and the antigen-binding residues of the murine monoclonal antibody
4D5. HER2 gene encodes a $185-\mathrm{kDa}$ transmembrane glycoprotein receptor $\left(\mathrm{p} 185^{\mathrm{HER} 2}\right)$, which is amplified in $25-30 \%$ of human breast cancers. When amplified, the gene produces high levels of HER2 surface receptor expression. Patients with breast cancer whose tumors demonstrate HER2 gene amplification and protein overexpression have an aggressive form of the disease with shortened disease-free and overall survival. Recent randomized clinical trials provide evidence that trastuzumab is an active and well-tolerated option for firstline treatment of women with HER2-overexpressing metastatic breast cancer $[5,6]$. However, their objective response rates were at most $20-30 \%$; thus, there is a need for markers to identify those patients who respond to trastuzumab.

Recently, we have treated 11 patients with metastatic breast cancer with first-line weekly trastuzumab monotherapy at patient request (they declined receiving cytotoxic chemotherapy). Their tumor HER2 status determined by immunohistochemistry (IHC) was IHC3+ (interpreted according to the manufacturer's test kit protocols). The response to treatment was evaluated according to the criteria of the Japan Mammary Cancer Society. We noticed that trastuzumab-responsive tumors contained much higher concentrations of NE (table 1). At present, the ligand that binds to HER2 is unknown. However, DiCamillo et al. [3] presented the novel finding that NEinitiated EGF signaling in lung fibroblasts is induced via cell surface EGF molecules directly released by NE in an autocrine loop fashion. Thus, in breast cancer with both HER2 overexpression and abundant NE, this proteolytic enzyme may trigger HER2 activation by releasing soluble form(s) of EGF-like molecule(s) and recruiting HER2 into signal transduction, causing these breast cancer cells to be responsive to trastuzumab. These preliminary findings suggest that $\mathrm{NE}$ in the primary tumor predicts responsiveness to trastuzumab treatment in patients with HER-2-overexpressing metastatic breast cancer.

\begin{tabular}{ll}
\hline KARGER & @ 2007 S. Karger GmbH, Freiburg \\
Fax +49 7614 52 07 14 & Accessible online at: \\
$\begin{array}{l}\text { E-mail Information@Karger.de } \\
\text { www.karger.com }\end{array}$ & www.karger.com/onk
\end{tabular}

Jun-ichi Yamashita, MD

Department of Breast Oncology

Okazaki City Medical Association Public Health Center

Tatsumi-Nishi 1-9-1, Okazaki 444-0875, Japan

Tel. +81 564-52 1572, Fax -54 0102

E-mail j-yamashita@okazaki-med.or.jp 
Table 1. Relation between immunoreactive neutrophil elastase concentration in tumor extracts and response to trastuzumab treatment

\begin{tabular}{lcccl}
\hline \multicolumn{2}{l}{ Trastuzumab responsiveness, $\mathrm{n}$} & & $\begin{array}{l}\text { Immunoreactive neutrophil elastase } \\
\mu \mathrm{g} / 100 \mathrm{mg} \text { protein }\end{array}$ \\
\cline { 1 - 2 } $\mathrm{CR}$ & PR & NC & PD & \\
\hline 1 & 4 & 0 & 0 & $12.31 \pm 5.22^{\mathrm{a}}$ \\
0 & 0 & 3 & 3 & $2.36 \pm 2.14$ \\
\hline
\end{tabular}

$\mathrm{CR}=$ Complete response $\mathrm{PR}=$ partial response $; \mathrm{NC}=$ no change $\mathrm{PD}=$ progressive disease $; \mathrm{CR}+\mathrm{PR}=$ responders; $\mathrm{NC}+\mathrm{PD}=$ nonresponders. ${ }^{\mathrm{a}} \mathrm{p}<0.001$ vs. nonresponder.

\section{References}

1 Yamashita J, Ogawa M, Ikei S, Omachi H, Yamashita S, Saishoji T, Nomura K, Sato H: Production of immunoreactive polymorphonuclear leukocyte elastase in human breast cancer cells. Possible role of polymorphonuclear leukocyte elastase in the progression of human breast cancer. Br J Cancer 1994;69:72-76.

2 Yamashita J, Ogawa M, Shirakusa T: Free-form neutrophil elastase is an independent marker predicting recurrence in primary breast cancer. J Leukoc Biol 1995;57:375-378.

3 DiCamillo SJ, Carreras I, Panchenko MV, Stone PJ, Nugent MA, Foster JA, Panchenko MP: Elastase-released epidermal growth factor recruits epidermal growth factor receptor and extracellular signal-regulated kinases to down-regulate tropoelastin mRNA in lung fibroblasts. J Biol Chem 2002;277:18938-18946.

4 Kohri K, Ueki IF, Nadel JA: Neutrophil elastase induces mucin production by ligand-dependent epidermal growth factor receptor activation. Am J Physiol Lung Cell Mol Physiol 2002;283:531-540.

5 Puglisi F, Piccart M: Trastuzumab and breast cancer. Are we just beyond the prologue of a fascinating story? Onkologie 2005;28:547-549.

6 D'Incalci M: Correlation of ErbB2 gene status, mRNA and protein expression. Onkologie 2006;29:246-247. 